\title{
Oxygen desaturation during sleep and exercise in patients with interstitial lung disease
}

\author{
B MIDGREN, L HANSSON, L ERIKSSON, P AIRIKKALA, D ELMQVIST
}

From the Department of Lung Medicine, Department of Clinical Physiology, and Department of Clinical Neurophysiology, University Hospital, Lund, Sweden

ABSTRACT The relations between mean and maximum fall in arterial oxygen saturation $\left(\mathrm{SaO}_{2}\right)$ during sleep, hypoxaemia during moderate and maximum exercise, and lung mechanics were studied in 16 patients with interstitial lung disease. Mean and minimum $\mathrm{SaO}_{2}$ during sleep were significantly related to each other and to daytime oxygenation but not to lung mechanics. Although the maximum fall in $\mathrm{SaO}_{2}$ during sleep was similar to the fall during maximum exercise (a level seldom achieved during normal daily activities), profound hypoxaemic episodes during sleep were rare and brief and therefore contributed little to the mean $\mathrm{SaO}_{2}$. The fall in mean $\mathrm{SaO}_{2}$ during sleep was not significant and was considerably less than during moderate exercise (average $0.5 v$ an estimated $4.5 \%, p<0.05$ ). It is therefore concluded that in patients with interstitial lung disease oxygen desaturation during sleep is mild and less severe than hypoxaemia during exercise.

Oxygen desaturation during sleep in chronic obstructive lung disease is well documented, and it has been shown that daytime concentrations of blood gases determine the absolute arterial oxygen saturation $\left(\mathrm{SaO}_{2}\right)$ levels during sleep ${ }^{12}$ as well as the severity of sleep induced fall in $\mathrm{SaO}_{2} \cdot{ }^{2-4}$ The conclusions in the few published studies on desaturation during sleep in patients with interstitial lung disease differ. Bye et $a l^{5}$ studied 13 patients with moderately severe disease (mean total lung capacity (TLC) $76 \%$ predicted, arterial oxygen pressure $\left(\mathrm{PaO}_{2}\right) 9.9 \mathrm{kPa}(74 \mathrm{~mm} \mathrm{Hg})$ ). They concluded that the minimum levels of $\mathrm{SaO}_{2}$ during sleep can be lower than during exercise. Mean levels, however, were not calculated. Perez-Padilla $e t$ $a l^{6}$ studied 11 more severely disabled patients (TLC $67 \%$ predicted, $\left.\mathrm{PaO}_{2} 9 \cdot 2 \mathrm{kPa}(69 \mathrm{~mm} \mathrm{Hg})\right)$ and found "considerable" desaturation during sleep. In contrast, McNicholas et al, ${ }^{7}$ who studied seven patients (vital capacity (VC) $50 \%$ predicted, $\mathrm{PaO}_{2} 9.0 \mathrm{kPa}$ $(68 \mathrm{~mm} \mathrm{Hg})$ ), stated that the desaturation during sleep was mild and less severe than in patients with chronic obstructive lung disease.

Previous reports have presented few quantitative

Address for reprint requests: Dr B Midgren, Department of Lung Medicine, University Hospital, S-221 85 Lund, Sweden.

Accepted 17 November 1986 data on the relation between daytime concentrations of blood gases and other physiological findings with $\mathrm{SaO}_{2}$ levels during sleep. We therefore investigated 16 patients with interstitial lung disease and documented desaturation during wakefulness to relate their $\mathrm{SaO}_{2}$ levels during sleep to daytime concentrations of blood gases at rest and during exercise and to lung volumes and lung resistance.

\section{Methods}

From November 1984 to December 1985 we studied all patients referred to our department with stable interstitial lung disease (diffuse fibrosis on $x$ ray examination, reduced lung volumes, and low lung compliance) and daytime hypoxaemia $\left(\mathrm{PaO}_{2} \leqslant 8 \mathrm{kPa}\right.$ $(60 \mathrm{~mm} \mathrm{Hg})$ at rest or on exercise or a fall in $\mathrm{PaO}_{2} \geqslant 2.5 \mathrm{kPa}(19 \mathrm{~mm} \mathrm{Hg})$ with exercise). Seventeen patients were eligible; none refused to take part in the study but one was excluded because her profound daytime hypoxaemia precluded a sleep study without oxygen supplementation.

Of the 16 patients studied nine had idiopathic pulmonary fibrosis, ${ }^{8}$ three had extrinsic allergic alveolitis, two had progressive systemic sclerosis, and one each had alveolar proteinosis and asbestosis. The diagnosis was verified histologically in 10 patients.

The study was approved by the medical ethics committee at the University of Lund. 
VC and TLC were measured by body plethysmography. ${ }^{9}$ The subjects breathed with a frequency of less than $1 \mathrm{~Hz}$ against a closed shutter for determination of thoracic gas volume. Values for VC and TLC are given in table 1 as per cent predicted. ${ }^{1011}$ Lung resistance $(\mathrm{RL})$ was recorded at a regulated flow of $1 \mathrm{l} / \mathrm{s}$ and at a static elastic recoil pressure of $7.5 \mathrm{~cm} \mathrm{H}_{2} \mathrm{O}$ measured with an oesophageal balloon specifically to assess intrinsic bronchial abnormalities. ${ }^{12}$ An exercise test was performed on an electrically braked bicycle ergometer (Siemens-Elema) with five minutes at each workload until exhaustion. Samples for arterial blood gas analysis were drawn from an indwelling radial catheter (Venflon, Viggo) at rest in the supine posture and while seated on the bicycle and during exercise at the end of each workload. The blood was analysed immediately using an automatic blood gas analyser (IL 413, Instrumentation Laboratories).

During the sleep study we assessed sleep stage, oronasal airflow, and thoracoabdominal motion during a single night as previously described. ${ }^{2}$ Four patients were investigated on a second occasion while receiving oxygen $1-2 \mathrm{l} / \mathrm{min}$ through nasal prongs. The continuous sleep recordings were staged conventionally ${ }^{13}$ using epochs of 30 seconds.

Oxygen saturation during sleep was measured in the majority of instances using a Biox III ear oximeter. ${ }^{14}$ On five occasions a Hewlett Packard 47201A instrument was used and the values thus obtained were adjusted so as to be comparable with the values obtained with the Biox oximeter. ${ }^{15}$ The signals from the oximeter were recorded on a Tarkan W + W 600 two channel strip chart recorder, manually synchronised with the electroencephalograph. The $\mathrm{SaO}_{2}$ recordings were then digitised using $30 \mathrm{~s}$ sampling intervals (corresponding to the epochs used for sleep staging) on a plotter (Hewlett Packard 7475A) connected to a microcomputer (IBM PC). Mean $\mathrm{SaO}_{2}$ was calculated separately for nocturnal wakefulness and non-REM (rapid eye movement) and REM sleep. The sleep induced fall in $\mathrm{SaO}_{2}$ is presented as fall in mean $\mathrm{SaO}_{2}$ (difference between mean $\mathrm{SaO}_{2}$ during nocturnal wakefulness and mean $\mathrm{SaO}_{2}$ during sleep) and as maximum fall (difference between mean $\mathrm{SaO}_{2}$ during nocturnal wakefulness and lowest $\mathrm{SaO}_{2}$ during sleep).

Statistical analysis was carried out with Student's $t$ test for paired and unpaired data or with Pearson's product-moment correlation. In some instances the $95 \%$ confidence interval is also presented.

\section{Results}

\section{WAKEFULNESS DATA}

The patients had a restrictive ventilatory defect with a mean TLC of $65.6 \%$ predicted (range 39-91\%) (table 1). Airflow limitation was present in about half of the patients, as shown by an abnormally high RL (normal upper limits $3 \mathrm{~cm} \mathrm{H}_{2} \mathrm{O} / \mathrm{l}$.s for men and $5 \mathrm{~cm} \mathrm{H}_{2} \mathrm{O} / \mathrm{l}$.s for women ${ }^{12}$ ), although the $\mathrm{FEV}_{1} / \mathrm{VC}$ ratio was within the normal limits in all patients.

In 14 patients the $\mathrm{PaO}_{2}$ was $<8 \mathrm{kPa}(60 \mathrm{~mm} \mathrm{Hg})$ at rest or during maximum exercise. Two patients were included only because of a fall in $\mathrm{PaO}_{2}$ of $>2.5 \mathrm{kPa}$ $(19 \mathrm{~mm} \mathrm{Hg})$; in these cases the fall in $\mathrm{SaO}_{2}$ during sleep and exercise was less than the average because they were operating on the flat part of the oxyhaemoglobin dissociation curve. $\mathrm{PaO}_{2}$ fell on average $0.65 \mathrm{kPa}(5 \mathrm{~mm} \mathrm{Hg}$ ) (confidence interval 0.1 to $1.2 \mathrm{kPa} ; 0.75$ to $9 \mathrm{~mm} \mathrm{Hg}$ ) from the supine to the sitting position at rest. The mean fall in $\mathrm{PaO}_{2}$ from supine rest to moderate exercise (20-50 $\mathrm{w}$ depending on the patient's condition) was $1.4 \mathrm{kPa}$ (CI 0.8 to $1.9 \mathrm{kPa} ; 6$ to $14 \mathrm{~mm} \mathrm{Hg}$ ) corresponding to a fall in calculated $\mathrm{SaO}_{2}$ of $4.5 \%$ (CI 1.4 to $7.5 \%$ ). The mean fall in $\mathrm{PaO}_{2}$ from supine rest to maximum exercise was $2.1 \mathrm{kPa} \quad(16 \mathrm{~mm} \mathrm{Hg}) \quad(\mathrm{CI} 1.5$ to $2.7 \mathrm{kPa} ; 11$ to $20 \mathrm{~mm} \mathrm{Hg}$ ) and was positively correlated with $\mathrm{PaO}_{2}$ at rest $(r=0.73, p<0.01)$. The average calculated $\mathrm{SaO}_{2}{ }^{16}$ during maximum exercise was $87 \%$ (range $68-94.5 \%)$. There was no correlation between the data on lung mechanics (TLC, VC, RL, or maximum exercise capacity) and level of oxygenation during rest or exercise or fall in $\mathrm{PaO}_{2}$ with exercise.

Table 1 Lung function during rest, exercise, and sleep

\begin{tabular}{|c|c|c|c|c|c|c|c|c|c|c|c|c|c|c|}
\hline & \multicolumn{6}{|c|}{ Resting data } & \multicolumn{3}{|c|}{ Exercise data } & \multicolumn{5}{|c|}{ Sleeping data } \\
\hline & $\begin{array}{l}T L C \\
(\% \\
\text { predicted })\end{array}$ & $\begin{array}{l}\text { VC } \\
\text { (\% } \\
\text { predicted) }\end{array}$ & $\begin{array}{l}R L \\
M / F \\
\left(\mathrm{~cm} \mathrm{H}_{2} \mathrm{O} /\right. \\
\text { l.s })\end{array}$ & $\begin{array}{l}\mathrm{PaO}_{2} \\
\text { supine } \\
(\mathrm{kPa})\end{array}$ & $\begin{array}{l}\mathrm{PaCO}_{2} \\
\text { supine } \\
(\mathrm{kPa})\end{array}$ & $\begin{array}{l}\text { Fall in } \\
\mathrm{PaO}_{2} \text { on } \\
\text { sitting } \\
(\mathrm{kPa})\end{array}$ & $\begin{array}{l}\text { Fall in } \\
\text { PaO }_{2} \\
\text { with } \\
\text { moderate } \\
\text { exercise } \\
(\mathrm{kPa})\end{array}$ & $\begin{array}{l}\text { Fall in } \\
\mathrm{PaO}_{2} \\
\text { with } \\
\text { maximum } \\
\text { exercise } \\
(\mathrm{kPa})\end{array}$ & $\begin{array}{l}W M A X \\
M / F \\
(w a t t)\end{array}$ & $\begin{array}{l}\mathrm{SaO}_{2} \\
\text { awake } \\
(\%)\end{array}$ & $\begin{array}{l}\mathrm{SaO}_{2} \\
\text { non- } \\
\mathrm{REM} \\
(\%)\end{array}$ & $\begin{array}{l}\mathrm{SaO}_{2} \\
\mathrm{REM} \\
(\%)\end{array}$ & $\begin{array}{l}\text { Fall in } \\
\text { mean } \\
\mathrm{SaO}_{2} \\
(\%)\end{array}$ & $\begin{array}{l}\text { Maxim } \\
\text { fall in } \\
\mathrm{SaO}_{2} \\
(\%)\end{array}$ \\
\hline $\begin{array}{l}\text { Mean } \\
\text { (SD) }\end{array}$ & $\begin{array}{c}66 \\
(16)\end{array}$ & $\begin{array}{c}65 \\
(16)\end{array}$ & $\begin{array}{c}3.5 / 5.4 \\
(0.9 / 1 \cdot 1)\end{array}$ & $\begin{array}{c}9 \cdot 1 \\
(1 \cdot 7)\end{array}$ & $\begin{array}{c}5 \cdot 0 \\
(0 \cdot 4)\end{array}$ & $\begin{array}{c}0.65^{*} \\
(1 \cdot 0)\end{array}$ & $\begin{array}{l}1 \cdot 35^{* * *} \\
(1 \cdot 0)\end{array}$ & $\begin{array}{l}2 \cdot 1 * * * \\
(1 \cdot 1)\end{array}$ & $\begin{array}{c}93 / 50 \\
(45 / 20)\end{array}$ & $\begin{array}{l}91 \cdot 3 \\
(3 \cdot 2)\end{array}$ & $\begin{array}{l}90 \cdot 9 \\
(3 \cdot 2)\end{array}$ & $\begin{array}{l}90.1 \\
(4.4)\end{array}$ & $\begin{array}{l}0.5 \mathrm{NS} \\
(0.96)\end{array}$ & $\begin{array}{l}8 \cdot 3^{* * *} \\
(4 \cdot 9)\end{array}$ \\
\hline
\end{tabular}

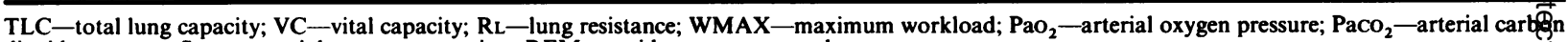
dioxide pressure; $\mathrm{SaO}_{2}$-arterial oxygen saturation; REM-rapid eye movement sleep.

NS-not significantly different from zero; ${ }^{*} p<0.05 ;{ }^{* * *} p<0.001$.

Conversion: SI to traditional units- $\mathrm{PaO}_{2}, \mathrm{PaCO}_{2} ; 1 \mathrm{kPa}=7.5 \mathrm{~mm} \mathrm{Hg}$. 
Table 2 Correlation between mean and lowest arterial oxygen saturation $\left(\mathrm{SaO}_{2}\right)$ during sleep and other variables

\begin{tabular}{|c|c|c|c|c|c|c|c|c|}
\hline $\mathrm{SaO}_{2}$ & $T L C$ & $V C$ & $R_{L}$ & $\begin{array}{l}\mathrm{PaCO}_{2} \text { at } \\
\text { rest }\end{array}$ & $\underset{\text { rest }}{\mathrm{PaO}_{2} \text { at }}$ & $\begin{array}{l}\mathrm{PaO}_{2} \text { during } \\
\text { moderate } \\
\text { exercise }\end{array}$ & $\begin{array}{l}\mathrm{PaO}_{2} \text { during } \\
\text { maximum } \\
\text { exercse }\end{array}$ & $\begin{array}{l}\mathrm{SaO}_{2} \text { during } \\
\text { nocturnal } \\
\text { wakefulness }\end{array}$ \\
\hline Mean & $\begin{array}{l}-0.044 \\
\text { NS }\end{array}$ & $\begin{array}{l}0 \cdot 28 \\
\mathrm{NS}\end{array}$ & $\begin{array}{l}0 \cdot 30 \\
\text { NS }\end{array}$ & $\begin{array}{l}0.45 \\
\text { NS }\end{array}$ & $\begin{array}{l}0.76 \\
* * *\end{array}$ & 0.66 & 0.74 & 0.96 \\
\hline Lowest & $\begin{array}{l}-0.33 \\
\text { NS }\end{array}$ & $\begin{array}{l}-0 \cdot 11 \\
\text { NS }\end{array}$ & $\begin{array}{l}0.53 \\
\text { NS }\end{array}$ & $\begin{array}{l}0.09 \\
\text { NS }\end{array}$ & $\begin{array}{l}0 \cdot 34 \\
\text { NS }\end{array}$ & $\begin{array}{l}0.20 \\
\text { NS }\end{array}$ & $\begin{array}{l}0.43 \\
\text { NS }\end{array}$ & 0.62 \\
\hline
\end{tabular}

TLC - total lung capacity; VC - vital capacity; $\mathrm{RL}_{\mathrm{L}}$-lung resistance; $\mathrm{PaCO}_{2}$ - arterial carbon dioxide pressure; $\mathrm{PaO}_{2}$-arterial oxygen pressure. NS-not significant; ${ }^{*} p<0.05 ;{ }^{* *} p<0.01 ;{ }^{* * *} p<0.001$.

SLEEP DATA

The total sleep time was on average 257 minutes, with only $13 \%$ spent in stage $3+4$ and $11 \%$ in REM sleep. One patient had an abnormal number of sleep apnoeas (total 53: 10 apnoeas/h) but the apnoeas were short, mean duration $12 \mathrm{~s}$, and not associated with noteworthy changes in $\mathrm{SaO}_{2}$.

The overall pattern of oxygenation level during sleep was stable with only a small difference between non-REM and REM sleep (fig 1). Three patients even showed an increase in $\mathrm{SaO}_{2}$ with sleep owing to hypoxaemic dips during periods of nocturnal wakefulness and stabilisation of $\mathrm{SaO}_{2}$ during sleep. Oxygen relieved hypoxaemia during sleep to the same extent as it did during wakefulness (fig 2) in the four patients studied.

The average mean $\mathrm{SaO}_{2}$ during sleep (all stages) was $90.8 \%$ compared with $91.3 \%$ for wakefulness. The values of mean $\mathrm{SaO}_{2}$ during sleep were highly significantly correlated with $\mathrm{PaO}_{2}$ and with mean $\mathrm{SaO}_{2}$ during (nocturnal) wakefulness $(\mathrm{r}=0.96$, $\mathrm{p}<0.001$ ) (table 2); there were no significant

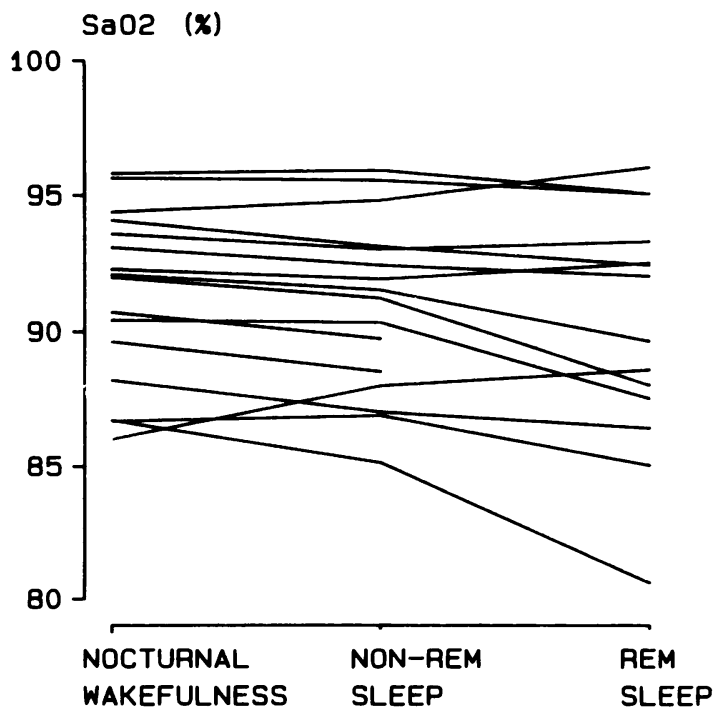

Fig 1 Mean values of arterial oxygen saturation ( $\mathrm{SaO}_{2}$ ) during wakefulness and non-REM and REM sleep for all patients.

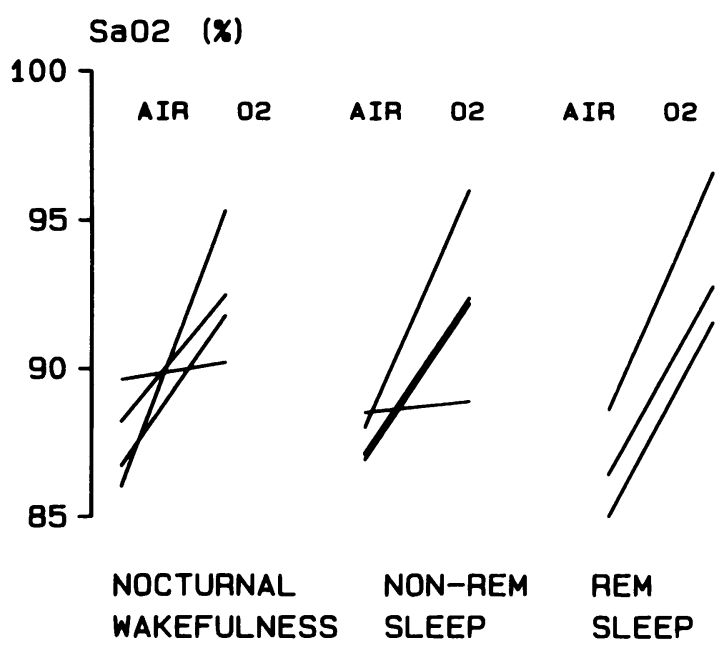

Fig 2 Arterial oxygen saturation $\left(\mathrm{SaO}_{2}\right)$ during wakefulness and non-REM and REM sleep for four patients investigated breathing room air and supplemental oxygen (1-2 l/min). One patient had no REM-sleep.

relations with awake arterial carbon dioxide pressure $\left(\mathrm{PaCO}_{2}\right)$, airway resistance, or lung volumes. The nadir values of $\mathrm{SaO}_{2}$ during sleep averaged $83 \%$ (range 70-92\%) and were significantly $(r=0.74$, $\mathrm{p}<0.01$ ) related to mean $\mathrm{SaO}_{2}$ during sleep, but the hypoxaemic dips were generally short and contributed little to the mean levels.

The fall in mean $\mathrm{SaO}_{2}$ with sleep was not significant (mean $0.5 \%, \mathrm{CI}-0.01$ to $1.01 \%$ ) and did not correlate with any of the variables, including the $\mathrm{SaO}_{2}$, during wakefulness. It was significantly less $(p<0.05)$ than the fall in calculated $\mathrm{SaO}_{2}$ with moderate exercise $(4.5 \%, \mathrm{CI} 1.4$ to 7.5$)$. The maximum fall in $\mathrm{SaO}_{2}$ with sleep was on average $8.3 \%$ (CI 5.7 to $10.9 \%$ ), which is not significantly greater than the average fall in calculated $\mathrm{SaO}_{2}$ with maximum exercise $(6 \cdot 7 \%$, CI 4.0 to $9 \cdot 5 \%)$.

\section{Discussion}

We selected patients with hypoxaemia during rest or exercise because a priori we considered it unlikely that we would find hypoxaemia during sleep in patients 
who had no hypoxaemia during the daytime. The average awake $\mathrm{SaO}_{2}$ calculated ${ }^{15}$ from oximeter readings during the sleep study was $92.7 \%$, and $\mathrm{SaO}_{2}$ calculated ${ }^{16}$ from measurements of $\mathrm{PaO}_{2}$ during the exercise study was $92.5 \%$. A comparison of data from our sleep and exercise studies therefore seems to be justified.

The fall in $\mathrm{PaO}_{2}$ observed during changing from supine to sitting position may be due to redistribution of blood flow to the basal parts of the lungs, which are often more affected by fibrosis. An alternative explanation is that the fall was exercise induced, since $\mathrm{PaO}_{2}$ sitting was measured after moving from the couch to the bicycle. The energy demand of normal daily activities, such as washing, dressing, standing, and walking about indoors, corresponds to a workload of approximately $30 \mathrm{w} .{ }^{17}$ Moderate exercise was thus defined as 20-50 w, depending on the maximum exercise level for the patient. We estimate that the patients perform at this level for at least six hours every day. We suggest therefore that the comparison of the level of oxygenation at this exercise level with the mean $\mathrm{SaO}_{2}$ during sleep (six to eight hours every day) probably reflects the relative contributions of exercise and sleep to oxygenation of these patients better than a comparison of transient extreme $\mathrm{SaO}_{2}$ values.

Desaturation during sleep in our patients was mild when compared with that in patients with chronic airways obstruction; ${ }^{2} 3$ episodes of desaturation were brief and seldom profound. The time spent in REM sleep was short (mean $11 \%$ of total sleeping time) compared with the normal $21 \%$ in this age group, ${ }^{18}$ but since the mean $\mathrm{SaO}_{2}$ in REM sleep was only slightly lower than in non-REM sleep even a considerable increase in REM sleep would have had little effect on the mean $\mathrm{SaO}_{2}$ (table 1).

Our patients were comparable to those of Perez-Padilla et $a l^{6}$ with respect to TLC and $\mathrm{PaO}_{2}$ during the daytime but we do not agree with their conclusion that patients with interstitial lung disease may have severe oxygen desaturation during sleep. Although our patients showed smaller falls in $\mathrm{SaO}_{2}$ during sleep than they reported, in both studies the desaturation was considerably less than is seen in patients with chronic obstructive lung disease. ${ }^{23} \mathrm{On}$ the other hand, our data support the opinion of McNicholas et $a l^{7}$ that oxygen desaturation during sleep in patients with interstitial lung disease is mild.

We conclude that sleep studies are unnecessary in the routine assessment and management of patients with interstitial lung disease.

We thank the Swedish National Association against Heart and Chest Diseases, the Swedish Society of Medical Sciences, and the Swedish Medical Research Council (grant no B86-04X-00084-22B) for financial support.

\section{References}

1 Catterall JR, Douglas NJ, Calverley PMA, et al. Transient hypoxemia during sleep in chronic obstructive pulmonary disease is not a sleep apnea syndrome. $A m \bar{\sigma}$ Rev Respir Dis 1983;128:24-9.

2 Midgren B, White T, Petersson K, Bryhn M, Airikkala $\frac{\text { D }}{\widetilde{T}}$ P, Elmqvist D. Nocturnal hypoxemia and cor@ pulmonale in severe chronic lung disease. Bull Eurœ Physiopathol Respir 1985;21:527-33.

3 Stradling JR, Lane DJ. Nocturnal hypoxaemia in chronic obstructive pulmonary disease. Clin Sci $\overrightarrow{\vec{\omega}}$ 1983;64:213-22.

4 Conway W, Kryger M, Timms R, Williams G. Hypercarbia predicts nocturnal desaturation in COPD [abstract]. Am Rev Respir Dis 1982;125(suppl):100.

5 Bye PTP, Issa M, Berthon-Jones M, Sullivan CE. Studies Cr of oxygenation during sleep in patients with interstitial w lung disease. Am Rev Respir Dis 1984;129:27-32.

6 Perez-Padilla R, West $\mathrm{P}$, Lertzman $\mathrm{M}$, Kryger $\mathrm{MH}$. 으 Breathing during sleep in patients with interstitial lung disease. Am Rev Respir Dis 1985;132:224-9.

7 McNicholas WT, Coffey M, FitzGerald MX. Ventilation and gas exchange during sleep in patients with inter- $\overrightarrow{0}$ stitial lung disease. Thorax 1986;41:777-82.

8 Crystal RG, Fulmer JD, Roberts WC, Moss ML, Line. BR, Reynolds HY. Idiopathic pulmonary fibrosis, clinical, histologic, radiographic, physiologic, scintigraphic, cytologic, and biochemical aspects. Ann $\bar{\partial}$ Intern Med 1976;85:769-88.

9 Jonson B. A method for determination of pulmonary elastic recoil and resistance at a regulated flow rate. Scand J Clin Lab Invest 1969;24:115-25.

10 Berglund E, Birath G, Bjure J, et al. Spirometric studies 3 in normal subjects. I Forced expirograms in subjects between 7 and 70 years of age. Acta Med Scand? 1963;173:185-92.

11 Grimby G, Söderholm B. Spirometric studies in normal subjects. III Static lung volumes and maximum voluntary ventilation in adults with a note on physical $\underset{\sigma}{\times}$ fitness. Acta Med Scand 1963;173:199-206.

12 Jonson B. Pulmonary mechanics in patients with pulmonary disease, studied with the flow regulator method. Scand J Clin Lab Invest 1970;25:374-90.

13 Rechtschaffen A, Kales A. A manual of standardized terminology, techniques and scoring systems for sleep $D$ stages of human subjects. Los Angeles: Brain Informa-음 tion Service-Brain Research Institute, University of $N$ California, 1968.

14 Tweedale PM, Douglas NJ. Evaluation of Biox IIA ear N oximeter. Thorax 1985;40:825-7.

15 Chapman KR, D'Urzo A, Rebuck AS. The accuracy and response characteristics of a simplified ear oximeter. Chest 1983;83:860-4.

16 Kelman GR, Nunn JF. Nomograms for correction of blood $\mathrm{PO}_{2}, \mathrm{PCO}_{2}, \mathrm{pH}$, and base excess for time and $\stackrel{\oplus}{+}$ temperature. J Appl Physiol 1966;21:1484-90.

17 Åstrand PO, Rodahl K. Applied work physiology. In: Textbook of work physiology: physiological bases of $\overrightarrow{\mathscr{Q}}$ exercise. 3rd ed. New York: McGraw-Hill, $\frac{\mathcal{D}_{\mathbb{D}}}{\mathbb{Q}}$ 1986:486-522.

18 Philipson L, Risberg AM, Ingvar DH. Normal sleep pattern analyzed statistically and studied by color $\Omega$ “dormograms." Sleep 1980;2:437-51. 